\title{
Huaishuia halophila gen. nov., sp. nov., isolated from coastal seawater
}

\author{
Correspondence \\ Xiao-Hua Zhang \\ xhzhang@ouc.edu.cn \\ Yong Yu \\ yuyong@pric.gov.cn
}

\author{
Hong Wang, ${ }^{1}$ Xiuming Zhang, ${ }^{1}$ Shulin Yan, ${ }^{1}$ Zizhong Oi, ${ }^{1}$ Yong $Y{ }^{2}$ \\ and Xiao-Hua Zhang ${ }^{1}$
}

${ }^{1}$ Key Laboratory of Marine Genetics and Breeding for Ministry of Education, College of Marine Life
Sciences, Ocean University of China, Qingdao, PR China
${ }^{2}$ SOA Key Laboratory for Polar Science, Polar Research Institute of China, Shanghai, PR China

A novel Gram-negative, non-motile bacterium, designated ZXM137 ${ }^{\top}$, was isolated from seawater collected from a coastal region of Qingdao, China, during a massive green algae (Enteromorpha prolifera) bloom. Strain ZXM137 ${ }^{\top}$ was strictly aerobic and did not accumulate poly- $\beta$-hydroxybutyrate. Growth occurred with $0.5-11.0 \%(\mathrm{w} / \mathrm{v}) \mathrm{NaCl}$, at $\mathrm{pH} 6-9$ (optimum of $\mathrm{pH}$ 7) and at $4-45{ }^{\circ} \mathrm{C}$ (optimum at $28^{\circ} \mathrm{C}$ ). It contained $\mathrm{Q}-10$ as the predominant ubiquinone and the major polar lipids were phosphatidylglycerol, phospholipids, and an unidentified aminolipid and lipid. The major cellular fatty acids of strain $Z X M 137^{\top}$ were $\mathrm{C}_{18: 1} \omega 7 c, \mathrm{C}_{18: 1} \omega 6 \mathrm{c}$ and 11-methyl $C_{18: 1} \omega 7 c$. The DNA G $+C$ content was 60.1 mol\%. Phylogenetic analysis based on $16 \mathrm{~S}$ rRNA gene sequences indicated that strain $\mathrm{ZXM} 137^{\top}$ formed a distinct evolutionary lineage within the Roseobacter group in the class Alphaproteobacteria. On the basis of phenotypic, chemotaxonomic and phylogenetic evidence, strain $Z X M 137^{\top}$ represents a novel species in a new genus, for which the name Huaishuia halophila gen. nov., sp. nov. is proposed; the type strain is ZXM137 ${ }^{\top}$ (=CGMCC $1.8891^{\top}=$ LMG $24854^{\top}$ ).
In recent years, many novel taxa within the class Alphaproteobacteria have been described. This class has been divided into nine orders and the Roseobacter group falls within the order Rhodobacterales. The Roseobacter group is one of the major groups of marine bacteria and is the only group in which cultivated bacteria are closely related to environmental clones (Buchan et al., 2005). Organisms belonging to the Roseobacter group have been detected in various marine environments, especially in association with marine algae (González et al., 2000). The phylogenetic diversity of the cultivable bacterial community in the coastal water of Qingdao during the Enteromorpha prolifera bloom was investigated and a novel strain $\left(\mathrm{ZXM} 137^{\mathrm{T}}\right)$ belonging to this group was isolated. The phylogenetically most closely related species to the isolate was Jannaschia pohangensis (Kim et al., 2008). The aim of the present study was to determine the exact taxonomic position of strain $\mathrm{ZXM137^{ \textrm {T } }}$ by using a polyphasic taxonomic approach.

A 10-fold-diluted surface seawater sample (diluted with sterile seawater) collected from the coastal region of

Abbreviations: DSMZ, Deutsche Sammlung von Mikroorganismen und Zellkulturen; $\mathrm{PHB}$, poly- $\beta$-hydroxybutyrate.

The GenBank/EMBL/DDBJ accession number for the 16S rRNA gene sequence of Huaishuia halophila ZXM137 ${ }^{\top}$ is FJ436725.

Four supplementary figures and a supplementary table are available with the online version of this paper.
Qingdao, China $\left(36.027^{\circ} \mathrm{N} 120.184^{\circ} \mathrm{E}\right)$ on June 28th 2008 during a massive green algae (Enteromorpha prolifera) bloom, was spread on marine agar 2216 (MA; Difco) and incubated at $28{ }^{\circ} \mathrm{C}$ for 5 days. A whitish colony, strain $\mathrm{ZXM} 137^{\mathrm{T}}$, was isolated on the plate and subsequently purified three times on MA at $28{ }^{\circ} \mathrm{C}$. Working cultures were maintained on MA at $28{ }^{\circ} \mathrm{C}$, and stocks were kept as suspensions in sterile $0.9 \%(\mathrm{w} / \mathrm{v})$ saline supplemented with $15 \%(\mathrm{v} / \mathrm{v})$ glycerol at $-70{ }^{\circ} \mathrm{C}$.

Jannaschia helgolandensis DSM $14858^{\mathrm{T}}$, obtained from the DSMZ (Deutsche Sammlung von Mikroorganismen und Zellkulturen) GmbH, Braunschweig, Germany, was used as the reference strain. Standard protocols, including those for Gram staining, catalase and oxidase activities, degradation of casein, starch, gelatin, DNA, Tween 80 and urea, nitrate reduction, and $\mathrm{H}_{2} \mathrm{~S}$ production from thiosulphate were used (Tindall et al., 2007). Cell morphology was studied using light microscopy (CX; Olympus) and transmission electron microscopy (JEOL; JEM-1200EX), with cells grown for $24 \mathrm{~h}$ at $28{ }^{\circ} \mathrm{C}$ on MA. The presence of flagella was determined using transmission electron microscopy after cells had been negatively stained with $1 \%(\mathrm{w} / \mathrm{v})$ phosphotungstic acid. Poly- $\beta$-hydroxybutyrate (PHB) accumulation was tested by fluorescence microscopy (BH2; Olympus) using Nile Blue A as a fluorescent stain (Tindall et al., 2007). Growth on trypticase soy agar (Difco) was tested. Growth under anaerobic conditions was 
determined after incubation in a dry-seal glass vacuum desiccator on MA for 3 days at $28{ }^{\circ} \mathrm{C}$, with 10 g gallic acid/ $100 \mathrm{ml} 10 \% \mathrm{NaOH}$ to consume oxygen. The temperature range for growth was determined on MA plates incubated at $4-55{ }^{\circ} \mathrm{C}$ for 10 days (Tindall et al., 2007). Growth in $0-15 \%$ $(\mathrm{w} / \mathrm{v}) \mathrm{NaCl}$ was investigated using synthetic marine ZoBell broth ( $5 \mathrm{~g}$ Bacto peptone, $1 \mathrm{~g}$ yeast extract and $0.1 \mathrm{~g} \mathrm{FePO}_{4}$ in 11 modified artificial seawater) supplied with various concentrations of $\mathrm{NaCl}(0-15.0 \%, \mathrm{w} / \mathrm{v})$, and this artificial seawater was modified from Lyman \& Fleming (1940), in which all of the $\mathrm{Na}^{+}$was replaced by appropriate $\mathrm{K}^{+}$. The $\mathrm{pH}$ range for growth was determined at $\mathrm{pH} 4-11$ (at $1 \mathrm{pH}$ unit intervals) in marine broth 2216E (MB; Difco) prepared with citrate/phosphate buffer $\left(0.2 \mathrm{~mol} \mathrm{l}^{-1}\right)$, Tris/ $\mathrm{HCl}$ buffer $\left(0.05 \mathrm{~mol} \mathrm{l}^{-1}\right)$ or $\mathrm{Na}_{2} \mathrm{CO}_{3} / \mathrm{NaOH}$ buffer $\left(0.025 \mathrm{~mol} \mathrm{l}^{-1}\right)$ (Breznak \& Costilow, 1994) by measuring changes in $\mathrm{OD}_{600}$ over time. Susceptibility to antibiotics was investigated on MA plates by using discs containing different antibiotics. Acid production and oxidation of substrates was determined by using the API 50CH system (bioMérieux) and Gram-negative MicroPlates (Biolog); other phenotypic and enzymic properties of strain $\mathrm{ZXM} 137^{\mathrm{T}}$ were tested using the API 20E, API 20NE and API ZYM systems with incubation at $28{ }^{\circ} \mathrm{C}$, according to the manufacturer's instructions except that sterile $1.5 \%(\mathrm{w} / \mathrm{v}) \mathrm{NaCl}$ was used to prepare the inocula. Morphological, cultural, physiological and biochemical characteristics of strain $\mathrm{ZXM} 137^{\mathrm{T}}$ are given in the genus and species descriptions (see below) or are shown in Table 1 (transmission electron micrographs of strain $\mathrm{ZXM}_{137^{\mathrm{T}}}$ are available as Supplementary Fig. S1, available in IJSEM Online).

For fatty acid methyl ester, respiratory quinone and polar

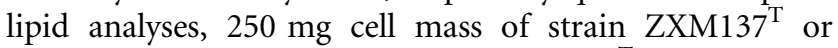
reference strain J. helgolandensis DSM $14858^{\mathrm{T}}$ was harvested from $\mathrm{MB}$ after incubation at $28{ }^{\circ} \mathrm{C}$ for $24 \mathrm{~h}$, when both of the communities reached the logarithmic stage. Analyses of respiratory quinones and polar lipids were carried out by the Identification Service and B. Tindall, DSMZ, Braunschweig, Germany. Fatty acid methyl esters were prepared and analysed according to the standard protocol described in the MIDI (Microbial Identification) system (TSBA version 6.0; Sasser, 1990). The DNA G + C content was determined by the method of Tamaoka \& Komagata (1984) with the modification that DNA was hydrolysed using nuclease P1 (Boehringer Mannheim) and the resultant nucleotides were analysed by reversed-phase HPLC.

For 16S rRNA gene sequencing, DNA was extracted from strain $\mathrm{ZXM} 137^{\mathrm{T}}$ and purified by standard methods (Ausubel et al., 1995). The 16S rRNA gene was amplified by PCR using two universal primers: B8F (5'-AGAGTTTGATCCTGGCTCAG-3') and B1510 (5'-GGTTACCTTGTTACGACTT-3'). The PCR product was purified using an agarose gel DNA purification kit (TaKaRa Biotechnology) and sequenced in both directions with primers B8F, B1510, interF1 (5'-TCGATACTGACGCTGAGGTG-3') and interR1 (5'-AGCGTCAGTATCGAGCCAGT- $3^{\prime}$ ) by Shanghai Biosune (China) with an Applied Biosystems automatic sequencer (ABI3730). The near-complete 16S rRNA gene sequence (1370 nt) of strain ZXM $137^{\mathrm{T}}$ was submitted to GenBank and EMBL to search for similar sequences using the BLAST algorithm. The identification of phylogenetic neighbours and the calculation of pairwise 16S rRNA gene sequence similarities were achieved using the EzTaxon server (http://www.eztaxon.org/; Chun et al., 2007). Sequences were aligned using CLUSTAL x 1.8 (Thompson et al., 1997) and edited manually using BioEdit Sequence Alignment Editor version 5.0.9 (Hall, 1999). Phylogenetic trees were constructed using the neighbourjoining method and maximum-parsimony methods with Kimura 2-state parameter model analyses implemented in the program MEGA version 4 (Tamura et al., 2007). Relationships among taxa were also established with the maximumlikelihood method in the PHYLIP 3.69 package (Felsenstein, 2009). In each case, bootstrap values were calculated based on 1000 replicates.

Pairwise analysis revealed that strain $\mathrm{ZXM} 137^{\mathrm{T}}$ exhibited highest $16 \mathrm{~S}$ rRNA gene sequence similarity with the type strain of Celeribacter neptunius (96.1\%), a recently described species, and showed $95.3 \%$ similarity with the type strain of J. pohangensis, which belongs to the family Rhodobacteraceae. Similarities between ZXM137 $7^{\mathrm{T}}$ and other members of the Alphaproteobacteria were below $94.7 \%$. The sequence similarities between $\mathrm{ZXM}_{137^{\mathrm{T}}}$ and the type strains of Roseovarius aestuarii, Thalassobacter stenotrophicus, Loktanella fryxellensis, Loktanella vestfoldensis and Loktanella koreensis were 94.3, 94.3, 92.2, 92.0 and $92.9 \%$, respectively. In the phylogenetic tree based on the neighbour-joining algorithm, strain ZXM137 $7^{\mathrm{T}}$ formed a clade with C. neptunius KMM $6012^{\mathrm{T}}$ that was related to members of the genus Roseovarius (Fig. 1), but formed a separate branch. According to the maximum-parsimony tree (Supplementary Fig. S2, available in IJSEM Online) and maximum-likelihood tree (Supplementary Fig. S3, available in IJSEM Online), ZXM137 ${ }^{\mathrm{T}}$ also formed a clade with $C$. neptunius KMM $6012^{\mathrm{T}}$. Strain ZXM137 ${ }^{\mathrm{T}}$ formed a phylogenetic distinct lineage within the family Rhodobacteraceae in these three phylogenetic trees and related to members of the genera Celeribacter, Roseovarius, Jannaschia and Thalassobacter. Thus, ZXM $137^{\mathrm{T}}$ represents a novel species in a new genus that is separate from members of related genera based on $16 \mathrm{~S}$ rRNA gene sequence analysis.

Strain ZXM137 ${ }^{\mathrm{T}}$ was Gram-negative, strictly aerobic, rodshaped $(0.8 \times 0.3 \mu \mathrm{m}$ in size $)$ bacterium that lacked flagella. Growth occurred in $0.5-11.0 \%(\mathrm{w} / \mathrm{v}) \mathrm{NaCl}$, at $\mathrm{pH}$ 6-9 (optimum growth at $\mathrm{pH} 7$ ) and at $4-45{ }^{\circ} \mathrm{C}$. Activities for lipase, amylase, gelatinase and casease were all negative. The distinctiveness of strain $Z X M 137^{\mathrm{T}}$ was strongly supported by its physiological and biochemical characteristics compared with members of related genera (Table 1); growth at $45{ }^{\circ} \mathrm{C}$ enabled strain $\mathrm{ZXM} 137^{\mathrm{T}}$ to be differentiated from all other related genera.

The most abundant fatty acid in strain $\mathrm{ZXM} 37^{\mathrm{T}}$ was $\mathrm{C}_{18: 1} \omega 7 c(56.7 \%)$ followed by $\mathrm{C}_{18: 1} \omega 6 c(13.0 \%)$, 11 methyl $\mathrm{C}_{18: 1} \omega 7 c(11.7 \%), \mathrm{C}_{18: 0}(6.9 \%), \mathrm{C}_{16: 0}(3.2 \%)$ and 


\section{Table 1. Phenotypic characteristics that differentiate Huaishuia gen. nov. from related genera}

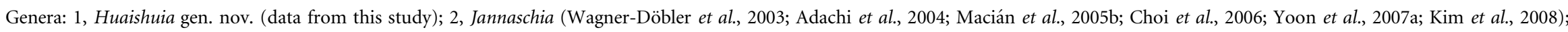

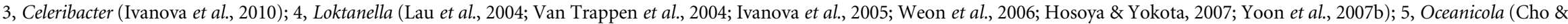

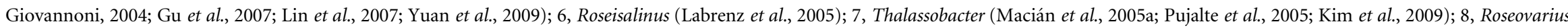
(Labrenz et al., 1999; González et al., 2003; Biebl et al., 2005; Boettcher et al., 2005; Wang et al., 2009). +, Positive; -, negative; v, varies between species and/or strains; ND, not determined.

\begin{tabular}{|c|c|c|c|c|c|c|c|c|}
\hline Characteristic & 1 & $2^{*}$ & 3 & 4 & 5 & 6 & 7 & 8 \\
\hline Colony colour $\dagger$ & $\mathrm{W}$ & $\mathrm{O}, \mathrm{W}, \mathrm{B}, \mathrm{R}, \mathrm{Br}(\mathrm{W})$ & $\mathrm{W}$ & $\mathrm{P}, \mathrm{O}, \mathrm{W}$ & $\mathrm{Y}, \mathrm{W}$ & $\mathrm{R}$ & $\mathrm{P}, \mathrm{Br}$ & $\mathrm{Y}, \mathrm{W}, \mathrm{P}, \mathrm{O}, \mathrm{R}$ \\
\hline Motility & - & $\mathrm{V}(-)$ & + & $\mathrm{V}$ & - & + & + & $\mathrm{V}$ \\
\hline PHB & - & $\mathrm{v}(+)$ & - & $\mathrm{ND}$ & + & + & + & ND \\
\hline Bud formation & - & $\mathrm{ND}(-)$ & $\mathrm{ND}$ & $\mathrm{ND}$ & ND & + & + & + \\
\hline $\mathrm{NaCl}$ range $(\%)$ & $0.5-11.0$ & $0.34-10.0$ & $1-8$ & $0-14$ & $0-10$ & $1-13$ & $0.85-8.0$ & $0.3-12.0$ \\
\hline \multicolumn{9}{|l|}{ Growth at: } \\
\hline $4{ }^{\circ} \mathrm{C}$ & + & $\mathrm{v}(-)$ & - & $\mathrm{V}$ & $\mathrm{V}$ & + & - & $\mathrm{v}$ \\
\hline $45^{\circ} \mathrm{C}$ & + & $-(-)$ & - & - & - & - & - & - \\
\hline ONPG & + & $\mathrm{v}(+)$ & ND & $\mathrm{v}$ & $\mathrm{v}$ & ND & $\mathrm{v}$ & - \\
\hline \multicolumn{9}{|l|}{ Hydrolysis of (in API 20E): } \\
\hline Urea & + & $\mathrm{V}(-)$ & + & $\mathrm{v}$ & $\mathrm{v}$ & $\mathrm{ND}$ & - & - \\
\hline Aesculin & + & $\mathrm{v}(-)$ & ND & $\mathrm{V}$ & $\mathrm{v}$ & $\mathrm{ND}$ & + & - \\
\hline Arginine dihydrolase & + & $-(-)$ & - & - & - & $\mathrm{ND}$ & - & - \\
\hline Lysine decarboxylase & + & $-(-)$ & - & - & $\mathrm{ND}$ & $\mathrm{ND}$ & - & + \\
\hline Ornithine decarboxylase & + & $-(-)$ & - & - & $\mathrm{ND}$ & $\mathrm{ND}$ & - & - \\
\hline \multicolumn{9}{|l|}{$\begin{array}{l}\text { Acid production from (in API } \\
50 \mathrm{CH} \text { ): }\end{array}$} \\
\hline Glycerol & - & $\mathrm{v}(+)$ & $\mathrm{ND}$ & $\mathrm{ND}$ & - & - & + & $\mathrm{v}$ \\
\hline Mannitol & + & $\mathrm{v}(+)$ & $\mathrm{ND}$ & $\mathrm{V}$ & $\mathrm{v}$ & - & $\mathrm{v}$ & $\mathrm{v}$ \\
\hline Trehalose & - & $-(-)$ & $\mathrm{ND}$ & + & $\mathrm{V}$ & - & - & $\mathrm{v}$ \\
\hline Cellobiose & - & $\mathrm{v}(+)$ & $\mathrm{ND}$ & + & $\mathrm{v}$ & - & - & - \\
\hline D-Fructose & + & $\mathrm{v}(+)$ & ND & + & $\mathrm{v}$ & - & + & - \\
\hline D-Galactose & + & $\mathrm{v}(+)$ & ND & + & + & - & $\mathrm{V}$ & $\mathrm{v}$ \\
\hline D-Glucose & + & $\mathrm{v}(+)$ & ND & $\mathrm{V}$ & $\mathrm{v}$ & - & + & $\mathrm{v}$ \\
\hline D-Mannose & + & $\mathrm{v}(+)$ & $\mathrm{ND}$ & - & $\mathrm{v}$ & - & $\mathrm{v}$ & - \\
\hline Arabinose & - & $-(-)$ & $\mathrm{ND}$ & $\mathrm{V}$ & $\mathrm{v}$ & - & $\mathrm{V}$ & - \\
\hline Sorbitol & - & $\mathrm{v}(+)$ & ND & $\mathrm{ND}$ & $\mathrm{V}$ & - & + & $\mathrm{ND}$ \\
\hline Major fatty acids & $\begin{array}{l}\mathrm{C}_{18: 1} \omega 7 c, \mathrm{C}_{18: 1} \omega 6 c \\
\text { 11-methyl } \mathrm{C}_{18: 1} \omega 7 c\end{array}$ & $\begin{array}{l}\mathrm{C}_{18: 1} \omega 7 c, \mathrm{C}_{18: 0} \\
\left(\mathrm{C}_{18: 1} \omega 7 c, \mathrm{C}_{18: 0}\right)\end{array}$ & $\begin{array}{c}\mathrm{C}_{18: 1} \omega 7 c \\
\mathrm{C}_{18: 1} \omega 9 c \\
\mathrm{C}_{18: 0}\end{array}$ & $\begin{array}{c}\mathrm{C}_{18: 1} \omega 7 c, \mathrm{C}_{16: 0} \\
\mathrm{C}_{10: 0} 3-\mathrm{OH}\end{array}$ & $\begin{array}{c}\mathrm{C}_{18: 1} \omega 7 c, \mathrm{C}_{16: 0} \\
\mathrm{C}_{19: 0} \text { cyclo, } \mathrm{C}_{18: 1} \\
\text { methyl }\end{array}$ & $\begin{array}{l}\mathrm{C}_{18: 1} \omega 7 c \\
\mathrm{C}_{16: 0,}, \mathrm{C}_{18: 0}\end{array}$ & $\begin{array}{c}\mathrm{C}_{18: 1} \omega 7 \mathrm{c}, 11-\text { methyl } \\
\quad \mathrm{C}_{18: 1} \omega 7 \mathrm{c}, \mathrm{C}_{16: 0}\end{array}$ & $\begin{array}{l}\mathrm{C}_{18: 1} \omega 7 c \\
\mathrm{C}_{16: 0}, \mathrm{C}_{18: 0}\end{array}$ \\
\hline DNA G $+\mathrm{C}$ content $(\mathrm{mol} \%)$ & 60.1 & $63.0-65.2$ & 59 & $56.8-66.4$ & $64.6-71.5$ & 67 & 56.0 and 59.1 & $58.6-66.0$ \\
\hline
\end{tabular}

${ }^{*}$ Data in parentheses are for the type strain of Jannaschia helgolandensis (data from this study).

$\dagger \mathrm{B}$, Beige; $\mathrm{Br}$, brown; $\mathrm{O}$, orange; $\mathrm{P}$, pink; $\mathrm{R}$, red; $\mathrm{W}$, white; $\mathrm{Y}$, yellow. 


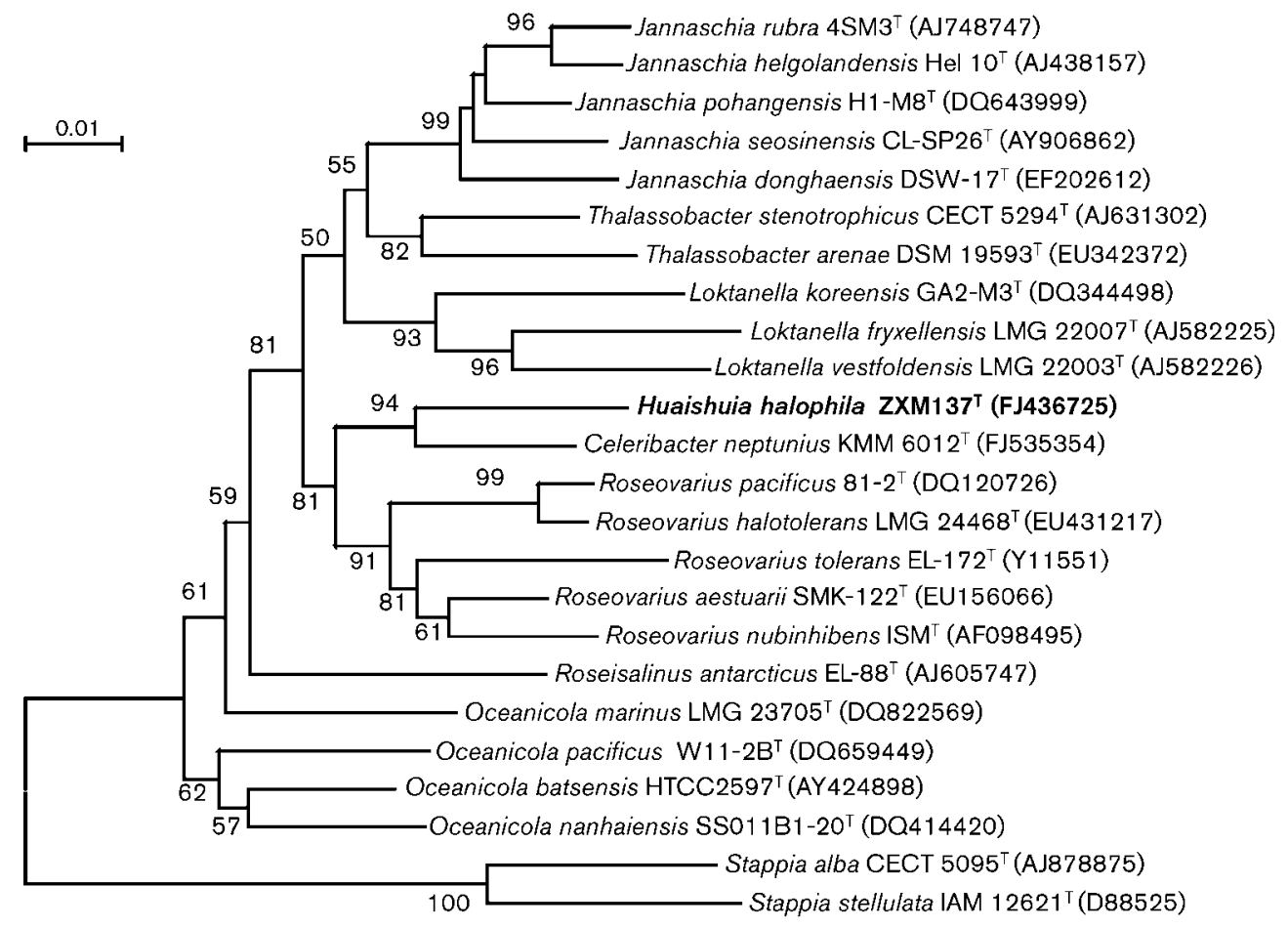

Fig. 1. Phylogenetic dendrogram of Huaishuia halophila $Z X M 137^{\top}$ and strains of related species based on 16S rRNA gene sequences. The tree was constructed using the neighbour-joining method with the software package MEGA version 4.0 (Tamura et al., 2007). Bootstrap values (\%) based on 1000 replicates are given at branching points. GenBank accession numbers are given in parentheses. Bar, 0.01 substitutions per nucleotide position.

10-methyl $\mathrm{C}_{19: 0}(2.9 \%)$. Consistent with neighbouring genera, ZXM137 ${ }^{\mathrm{T}}$ contained $\mathrm{C}_{18: 1} \omega 7 c$ as the major fatty acid. A large amount of $\mathrm{C}_{18: 1} \omega 6 c$ was detected in strain ZXM $137^{\mathrm{T}}$ but this fatty acid was not found in members of other related genera (Table 1 and Supplementary Table S1, available in IJSEM Online).

The predominant ubiquinone detected in strain $\mathrm{ZXM} 137^{\mathrm{T}}$ was Q-10 at a peak area ratio of $100 \%$, which was consistent with some species in the family Rhodobacteraceae, such as $J$. pohangensis, R. aestuarii and L. koreensis (Kim et al., 2008; Yoon et al., 2008; Weon et al., 2006). Major polar lipids in strain $\mathrm{ZXM} 137^{\mathrm{T}}$ were phosphatidylglycerol, phospholipids, and an unidentified aminolipid and lipid (Supplementary Fig. S4, available in IJSEM Online). Some species in the genera Jannaschia, Thalassobacter and Roseovarius were found to have phosphatidylglycerol but they also had diphosphatidylglycerol and phosphatidylcholine as major polar lipids (Wagner-Döbler et al., 2003; Macián et al., 2005a; Labrenz et al., 1999), which were not found in ZXM137 ${ }^{\mathrm{T}}$. The DNA G $+\mathrm{C}$ content of strain $\mathrm{ZXM} 137^{\mathrm{T}}$ was $60.1 \mathrm{~mol} \%$.

Therefore, on the basis of phenotypic, phylogenetic and genetic evidence, strain ZXM137 $7^{\mathrm{T}}$ should be classified as a representative of a novel species in a new genus, for which the name Huaishuia halophila gen. nov., sp. nov. is proposed.

\section{Description of Huaishuia gen. nov.}

Huaishuia (Huai.shu'i.a. N.L. fem. n. Huaishuia named after Professor Huai-Shu $\mathrm{Xu}$, who discovered the special live form viable but non-culturable state of bacteria).

Gram-negative, strictly aerobic, slightly halophilic. Cells are non-motile rods. PHB accumulation is not observed. Positive for cytochrome oxidase and catalase. The major cellular fatty acids are $\mathrm{C}_{18: 1} \omega 7 c, \mathrm{C}_{18: 1} \omega 6 c$ and 11-methyl $\mathrm{C}_{18: 1} \omega 7 c$. The major polar lipids are phosphatidylglycerol, phospholipids, and an unidentified aminolipid and lipid. Phylogenetically, the genus Huaishuia is a member of Roseobacter group in the class Alphaproteobacteria. The type species is Huaishuia halophila.

\section{Description of Huaishuia halophila sp. nov.}

Huaishuia halophila [ha.lo.phi'la. Gr. n. hals halos, salt; N.L. adj. philus - $a$-um (from Gr. adj. philos - $\hat{e}-o n$ ) friend, loving; N.L. fem. adj. halophila salt-loving].

In addition to the characteristics that define the genus, the type species has the following characteristics. Cells are approximately $0.8 \mu \mathrm{m}$ in length by $0.3 \mu \mathrm{m}$ in width. Colonies on MA are light white, circular, smooth and convex with an entire edge. Growth occurs on trypticase soy agar. Grows in $0.5-11 \%(\mathrm{w} / \mathrm{v}) \mathrm{NaCl} ; \mathrm{Na}^{+}$is required 
for growth and growth is not detected without ASW. Grows at $\mathrm{pH}$ 6-9 and $4-45{ }^{\circ} \mathrm{C}$ (optimum growth at $\mathrm{pH} 7$ and $28{ }^{\circ} \mathrm{C}$ ). No growth is detected at $0{ }^{\circ} \mathrm{C}$ or $50{ }^{\circ} \mathrm{C}$. Hydrolyses aesculin and urea (in API 20E), but not starch, casein, gelatin, DNA or Tween 80. Negative for nitrate reduction, Voges-Proskauer test, and $\mathrm{H}_{2} \mathrm{~S}$ and indole production. Weakly positive for alginase. According to API $20 \mathrm{E}$, positive for $\beta$-galactosidase, arginine dihydrolase, lysine decarboxylase and ornithine decarboxylase, but negative for tryptophan deaminase. According to API ZYM, positive for alkaline phosphatase, esterase (C4), esterase (C8), leucine arylamidase, acid phosphatase, naphthol-AS-BI-phosphohydrolase, $\alpha$-galactosidase, $\beta$-glucosidase and $\alpha$-glucosidase, but negative for lipase (C14), valine arylamidase, cystine arylamidase, trypsin, $\alpha$-chymotrypsin, $\beta$-glucuronidase, $N$-acetyl- $\beta$-glucosaminidase, $\alpha$ mannosidase and $\alpha$-fucosidase. Citrate utilization is positive. According to API $50 \mathrm{CH}$, acids are produced from the following substrates: D-galactose, D-glucose, D-fructose, D-mannose, L-rhamnose, inositol and D-mannitol. According to API $50 \mathrm{CH}$, acids are not produced from the following substrates: glycerine, erythritol, D-arabinose, L-arabinose, D-ribose, D-xylose, L-xylose, D-adonitol, methyl $\beta$-D-xylopyranoside, L-sorbose, dulcitol, D-sorbitol, methyl $\alpha$-D-mannopyranoside, methyl $\alpha$-D-glucopyranoside, $\mathrm{N}$-acetylglucosamine, amygdalin, arbutin, aesculin, salicin, cellobiose, maltose, lactose, melibiose, sucrose, trehalose, inulin, melezitose, raffinose, starch, glycogen, xylitol, gentiobiose, turanose, D-lyxose, D-tagatose, Dfucose, L-fucose, D-arabitol, L-arabitol, potassium 2-ketogluconate, potassium 5-ketogluconate and potassium gluconate. According to API 20NE, capric acid, adipic acid and trisodium citrate are hydrolysed, but malic acid is not hydrolysed. According to Biolog GN, the following substrates are oxidized: dextrin, Tween 80 , L-rhamnose, sucrose, monomethyl succinate, acetic acid, citric acid, $\alpha$-, $\beta$ - and $\gamma$-hydroxybutyric acid, $\alpha$-ketoglutaric acid, succinic acid and L-glutamic acid. Resistant to $30 \mu \mathrm{g}$ vancomycin and $2 \mu \mathrm{g}$ clindamycin, but sensitive to $30 \mu \mathrm{g}$ midecamycin, $10 \mu \mathrm{g}$ norfloxacin, $5 \mu \mathrm{g}$ ofloxacin, $5 \mu \mathrm{g}$ ciprofloxacin, $100 \mathrm{U}$ polymyxin $\mathrm{B}, 75 \mu \mathrm{g}$ sulfamethoxazole, $300 \mu \mathrm{g}$ furazolidone, $30 \mu \mathrm{g}$ tetracycline, $30 \mu \mathrm{g}$ ceftriaxone, $75 \mu \mathrm{g}$ cefoperazone, $30 \mu \mathrm{g}$ amikacin, $10 \mu \mathrm{g}$ gentamicin, $30 \mu \mathrm{g}$ kanamycin, $30 \mu \mathrm{g}$ neomycin, $30 \mu \mathrm{g}$ chloromycetin, $30 \mu \mathrm{g}$ doxycycline, $30 \mu \mathrm{g}$ minocycline, $15 \mu \mathrm{g}$ erythromycin, $10 \mathrm{U}$ penicillin, $1 \mu \mathrm{g}$ oxacillin sodium, $10 \mu \mathrm{g}$ ampicillin, $100 \mu \mathrm{g}$ carbenicillin, $100 \mu \mathrm{g}$ piperacillin, $30 \mu \mathrm{g}$ cephalothin IV, $30 \mu \mathrm{g}$ cephalothin V, $30 \mu \mathrm{g}$ cephalothin VI, $30 \mu \mathrm{g}$ cefuroxime and $30 \mu \mathrm{g}$ ceftazidime. The predominant ubiquinone is Q-10. Major polar lipids are phosphatidylglycerol, phospholipids, and an unidentified aminolipid and lipid.

The type strain is $\mathrm{ZXM} 37^{\mathrm{T}}\left(=\mathrm{CGMCC} 1.8891^{\mathrm{T}}=\mathrm{LMG}\right.$ $24854^{\mathrm{T}}$ ), isolated from seawater collected from a coastal region of Qingdao, China, during a massive green algae (Enteromorpha prolifera) bloom. The DNA G $+\mathrm{C}$ content is $60.1 \mathrm{~mol} \%$ (determined by HPLC).

\section{Acknowledgements}

This work was supported by the National High Technology R\&D Program of China (grant 2007AA09Z434) and the National Natural Science Foundation of China (grant 40876067).

\section{References}

Adachi, M., Kanno, T., Okamoto, R., Shinozaki, A., Fujikawa-Adachi, K. \& Nishijima, T. (2004). Jannaschia cystaugens sp. nov., an Alexandrium (Dinophyceae) cyst formation-promoting bacterium from Hiroshima Bay, Japan. Int J Syst Evol Microbiol 54, 1687-1692.

Ausubel, F. M., Brent, R., Kingston, R. E., Moore, D. D., Seidman, J. G., Smith, J. A. \& Struhl, K. (editors) (1995). Short Protocols in Molecular Biology: a Compendium of Methods from Current Protocols in Molecular Biology, 3rd edn. New York: Wiley.

Biebl, H., Allgaier, M., Lünsdorf, H., Pukall, R., Tindall, B. J. \& Wagner-Döbler, I. (2005). Roseovarius mucosus sp. nov., a member of the Roseobacter clade with trace amounts of bacteriochlorophyll $a$. Int J Syst Evol Microbiol 55, 2377-2383.

Boettcher, K. J., Geaghan, K. K., Maloy, A. P. \& Barber, B. J. (2005). Roseovarius crassostreae sp. nov., a member of the Roseobacter clade and the apparent cause of juvenile oyster disease (JOD) in cultured Eastern oysters. Int J Syst Evol Microbiol 55, 1531-1537.

Breznak, J. A. \& Costilow, R. N. (1994). Physicochemical factors in growth. In Methods for General and Molecular Bacteriology, pp. 137154. Edited by P. Gerhardt, R. G. E. Murray, W. A. Wood \& N. R. Krieg. Washington, DC: American Society for Microbiology.

Buchan, A., González, J. M. \& Moran, M. A. (2005). Overview of the marine roseobacter lineage. Appl Environ Microbiol 71, 5665-5677.

Cho, J.-C. \& Giovannoni, S. J. (2004). Oceanicola granulosus gen. nov., sp. nov. and Oceanicola batsensis sp. nov., poly- $\beta$-hydroxybutyrateproducing marine bacteria in the order 'Rhodobacterales'. Int J Syst Evol Microbiol 54, 1129-1136.

Choi, D. H., Yi, H., Chun, J. \& Cho, B. C. (2006). Jannaschia seosinensis sp. nov., isolated from hypersaline water of a solar saltern in Korea. Int J Syst Evol Microbiol 56, 45-49.

Chun, J., Lee, J.-H., Jung, Y., Kim, M., Kim, S., Kim, B. K. \& Lim, Y. W. (2007). EzTaxon: a web-based tool for the identification of prokaryotes based on $16 \mathrm{~S}$ ribosomal RNA gene sequences. Int J Syst Evol Microbiol 57, 2259-2261.

Felsenstein, J. (2009). PHYLIP (phylogeny inference package) v3.69. Distributed by the author. Department of Genome Sciences, University of Washington, Seattle, USA.

González, J. M., Simó, R., Massana, R., Covert, J. S., Casamayor, E. O., Pedrós-Alió, C. \& Moran, M. A. (2000). Bacterial community structure associated with a dimethylsulfoniopropionate-producing North Atlantic algal bloom. Appl Environ Microbiol 66, 4237-4246.

González, J. M., Covert, J. S., Whitman, W. B., Henriksen, J. R., Mayer, F., Scharf, B., Schmitt, R., Buchan, A., Fuhrman, J. A. \& other authors (2003). Silicibacter pomeroyi sp. nov. and Roseovarius nubinhibens sp. nov., dimethylsulfoniopropionate-demethylating bacteria from marine environments. Int J Syst Evol Microbiol 53, 1261-1269.

Gu, J., Guo, B., Wang, Y.-N., Yu, S.-L., Inamori, R., Qu, R., Ye, Y.-G. \& $\mathrm{Wu}, \mathrm{X}$. -L. (2007). Oceanicola nanhaiensis sp. nov., isolated from sediments of the South China Sea. Int J Syst Evol Microbiol 57, 157160.

Hall, T. A. (1999). BioEdit: a user-friendly biological sequence alignment editor and analysis program for windows 95/98/NT. Nucleic Acids Symp Ser 41, 95-98.

Hosoya, S. \& Yokota, A. (2007). Loktanella atrilutea sp. nov., isolated from seawater in Japan. Int J Syst Evol Microbiol 57, 1966-1969. 
Ivanova, E. P., Zhukova, N. V., Lysenko, A. M., Gorshkova, N. M., Sergeev, A. F., Mikhailov, V. V. \& Bowman, J. P. (2005). Loktanella agnita sp. nov. and Loktanella rosea sp. nov., from the north-west Pacific Ocean. Int J Syst Evol Microbiol 55, 2203-2207.

Ivanova, E. P., Webb, H., Christen, R., Zhukova, N. V., Kurilenko, V. V., Kalinovskaya, N. I. \& Crawford, R. J. (2010). Celeribacter neptunius gen. nov., sp. nov., a new member of the class Alphaproteobacteria. Int J Syst Evol Microbiol 60, 1620-1625.

Kim, B. Y., Yoo, S. H., Weon, H. Y., Jeon, Y. A., Hong, S. B., Go, S. J., Stackebrandt, E. \& Kwon, S. W. (2008). Jannaschia pohangensis sp. nov., isolated from seashore sand in Korea. Int J Syst Evol Microbiol 58, 496-499.

Kim, B. Y., Weon, H. Y., Son, J. A., Lee, C. M., Hong, S. B., Jeon, Y. A., Koo, B. S. \& Kwon, S. W. (2009). Thalassobacter arenae sp. nov., isolated from sea sand in Korea. Int J Syst Evol Microbiol 59, 487-490.

Labrenz, M., Collins, M. D., Lawson, P. A., Tindall, B. J., Schumann, P. \& Hirsch, P. (1999). Roseovarius tolerans gen. nov., sp. nov., a budding bacterium with variable bacteriochlorophyll a production from hypersaline Ekho Lake. Int J Syst Bacteriol 49, 137-147.

Labrenz, M., Lawson, P. A., Tindall, B. J., Collins, M. D. \& Hirsch, P. (2005). Roseisalinus antarcticus gen. nov., sp. nov., a novel aerobic bacteriochlorophyll $a$-producing $\alpha$-proteobacterium isolated from hypersaline Ekho Lake, Antarctica. Int J Syst Evol Microbiol 55, 41-47.

Lau, S. C. K., Tsoi, M. M. Y., Li, X., Plakhotnikova, I., Wu, M., Wong, P.-K. \& Qian, P.-Y. (2004). Loktanella hongkongensis sp. nov., a novel member of the $\alpha$-Proteobacteria originating from marine biofilms in Hong Kong waters. Int J Syst Evol Microbiol 54, 2281-2284.

Lin, K. Y., Sheu, S. Y., Chang, P. S., Cho, J. C. \& Chen, W. M. (2007). Oceanicola marinus sp. nov., a marine alphaproteobacterium isolated from seawater collected off Taiwan. Int J Syst Evol Microbiol 57, 16251629.

Lyman, J. \& Fleming, R. H. (1940). Composition of seawater. J Mar Res 3, 134-146.

Macián, M. C., Arahal, D. R., Garay, E., Ludwig, W., Schleifer, K. H. \& Pujalte, M. J. (2005a). Thalassobacter stenotrophicus gen. nov., sp. nov., a novel marine $\alpha$-proteobacterium isolated from Mediterranean sea water. Int J Syst Evol Microbiol 55, 105-110.

Macián, M. C., Arahal, D. R., Garay, E., Ludwig, W., Schleifer, K. H. \& Pujalte, M. J. (2005b). Jannaschia rubra sp. nov., a red-pigmented bacterium isolated from sea water. Int J Syst Evol Microbiol 55, 649653.

Pujalte, M. J., Macián, M. C., Arahal, D. R. \& Garay, E. (2005). Thalassobacter stenotrophicus Macian et al. 2005 is a later synonym of Jannaschia cystaugens Adachi et al. 2004, with emended description of the genus Thalassobacter. Int J Syst Evol Microbiol 55, 1959-1963.
Sasser, M. (1990). Identification of bacteria by gas chromatography of cellular fatty acids. Technical Note 101. Newark, DE: MIDI.

Tamaoka, J. \& Komagata, K. (1984). Determination of DNA base composition by reversed-phase high-performance liquid chromatography. FEMS Microbiol Lett 25, 125-128.

Tamura, K., Dudley, J., Nei, M. \& Kumar, S. (2007). MEGA4: Molecular Evolutionary Genetics Analysis (MEGA) software version 4.0. Mol Biol Evol 24, 1596-1599.

Thompson, J. D., Gibson, T. J., Plewniak, F., Jeanmougin, F. \& Higgins, D. G. (1997). The CLUSTAL_X windows interface: flexible strategies for multiple sequence alignment aided by quality analysis tools. Nucleic Acids Res 25, 4876-4882.

Tindall, B. J., Sikorski, J., Smibert, R. M. \& Krieg, N. R. (2007). Phenotypic characterization and the principles of comparative systematics. In Methods for General and Molecular Microbiology, pp. 330-393. Edited by C. A. Reddy, T. J. Beveridge, J. A. Breznak, G. Marzluf, T. M. Schmidt \& L. R. Snyder. Washington, DC: American Society for Microbiology.

Van Trappen, S., Mergaert, J. \& Swings, J. (2004). Loktanella salsilacus gen. nov., sp. nov., Loktanella fryxellensis sp. nov. and Loktanella vestfoldensis sp. nov., new members of the Rhodobacter group, isolated from microbial mats in Antarctic lakes. Int J Syst Evol Microbiol 54, 1263-1269.

Wagner-Döbler, I., Rheims, H., Felske, A., Pukall, R. \& Tindall, B. J. (2003). Jannaschia helgolandensis gen. nov., sp. nov., a novel abundant member of the marine Roseobacter clade from the North Sea. Int J Syst Evol Microbiol 53, 731-738.

Wang, B. J., Tan, T. F. \& Shao, Z. Z. (2009). Roseovarius pacificus sp. nov., isolated from deep-sea sediment. Int J Syst Evol Microbiol 59, 1116-1121.

Weon, H. Y., Kim, B. Y., Yoo, S. H., Kim, J. S., Kwon, S. W., Go, S. J. \& Stackebrandt, E. (2006). Loktanella koreensis sp. nov., isolated from sea sand in Korea. Int J Syst Evol Microbiol 56, 2199-2202.

Yoon, J. H., Kang, S. J., Park, S. \& Oh, T. K. (2007a). Jannaschia donghaensis sp. nov., isolated from seawater of the East Sea, Korea. Int J Syst Evol Microbiol 57, 2132-2136.

Yoon, J.-H., Kang, S.-J., Lee, S.-Y. \& Oh, T.-K. (2007b). Loktanella maricola sp. nov., isolated from seawater of the East Sea in Korea. Int $J$ Syst Evol Microbiol 57, 1799-1802.

Yoon, J. H., Kang, S. J. \& Oh, T. K. (2008). Roseovarius aestuarii sp. nov., isolated from a tidal flat of the Yellow Sea in Korea. Int J Syst Evol Microbiol 58, 1198-1202.

Yuan, J., Lai, Q.-L., Wang, B.-J., Sun, F.-Q., Liu, X., Du, Y., Li, G., Gu, L., Zheng, T. \& Shao, Z. (2009). Oceanicola pacificus sp. nov., isolated from a deep-sea pyrene-degrading consortium. Int $J$ Syst Evol Microbiol 59, 1158-1161. 